\title{
Chip Formation Comparison- Merchant's Model vs. Model with Rounded Cutting Edge
}

Katarína Monková ${ }^{1,3}$, Jaromír Markovič ${ }^{2}$, Peter Pavol Monka ${ }^{1,3}$, Jan Řehoř ${ }^{3,4}$, Peter Pastucha ${ }^{1}$

${ }^{1}$ Technical University of Košice, Faculty of Manufacturing Technologies with seat in Prešov, Bayerova 1, 08001 Prešov, Slovakia. E-mail: peter.monka@tuke.sk, katarina.monkova@tuke.sk,ppastucha@gmail.com

${ }^{2}$ Slovak Metrological Society, Hviezdoslavova 1124/31, 97401 Banská Bystrica, Slovakia. E-mail: slm@slm.sk

${ }^{3}$ Regional Technological Institute, University of West Bohemia, Univerzitní 8, 30614 Pilsen, Czech Republic. E-mail: monka@rti.zcu.cz, rehor4@rti.zcu.cz

${ }^{4}$ Department of Machining Technology, University of West Bohemia, Univerzitní 22, 30614 Pilsen, Czech Republic. Email: rehor4@kto.zcu.cz

Merchant's model of chips formation considers an "ideal" (sharp) cutting edge. However, nowadays many manufacturers of cutting tools modify the tool geometry with the goal to increase the tool life and to improve the surface quality. The processes, at which the modified tools are used, go along with chip formation and physical phenomena that differ from Merchant's model.

The article deals with the simulation of chip formation at various ratios of rounded cutting edge and cutting thickness. Aim of the research has been focused on the interpretation of new knowledge from the cutting theory. Authors have tried to understand the theory of cutting process by means of simulation and provide the recommendations for practical usage. They explain the differences between the Merchant's model with a sharp edge and a model with a rounded cutting edge. The contribution describes changes and manifestations of physical phenomena result from given conditions. There were also simulated dependencies of the tool load on the radius of cutting edge in the article. Achieved results will enable not only better integration of cutting tools into the manufacturing, but they also allow to increase the machining efficiency.

Keywords: Cutting Edge, Merchant'S Model, Simulation, Chip Formation

\section{Acknowledgement}

The paper was published thanks to international cooperation of authors within the projects/grants VEGA 1/0614/15|KEGA 087TUKE-4/2015|KEGA 013TUKE-4/2014 with direct support of Ministry of Education of the Slovak Republic and project CZ.1.05/2.1.00/03.0093 - Regional Technological Institute covered by the European Regional Development Fund and the state budget of the Czech Republic. The authors would like to express their gratitude to the both above mentioned institution for financial support of the research activities.

\section{References}

[1] ANTIĆ, A. et al (2013). Influence of tool wear on the mechanism of chips segmentation and tool vibration In: Tehnicki Vjesnik, Vol. 20, 1, pp. 105 - 112

[2] BOUZAKIS, K. D. et.al (2014). Effect of cutting edge preparation of coated tool end their performance in milling var-ious materials. In: CIRP Journal of Manufacturing Science and Technology 7, pp. 264-273

[3] FULEMOVA, J., JANDA, Z.(2014). Influence of the Cutting Edge Radius and the Cutting Edge Preparation on Tool Life and Cutting Forces at Inserts with Wiper Geometry. In: Procedia Engineering 69, pp. 565-573.

[4] KARPAT, Y., ÖTZEL, T. (2008). Mechanics of high speed cutting with curvilinear edge tools. In: International Journal of Machine Tools and Manufacture, 48, pp. 195-208

[5] KARPUSCHEWSKI, B., SCHMIDT, K. BEŇO, J. et al (2014). Measuring procedures of cutting edge preparation when hard turning with coated ceramics tool inserts In: Measurement, 55, pp. 627-640

[6] KROLCZYK, G. M. et al (2015). Determination of tool life and research wear during duplex stainless steel turning In: Source of the Document Archives of Civil and Mechanical Engineering, pp. 473-476

[7] MAŇKOVÁ, I., VRABEL, M., BEŇO, J. et al (2013). Application of Taguchi method and surface response methodology to evaluate of mathematical models to chip deformation when drilling with coated and un-coated twist drills, In: Manufacturing Technology, Volume 13, Issue 4, pp. 492-499

[8] MERCHANT M. E. (1945). Mechanics of the metal cutting process, I: orthogonal cutting. Journal of Applied Physics 1945,16, pp. 267-275.

[9] MERCHANT M. E. (1945). Mechanics of the metal cutting process, II: plasticity conditions in orthogonal cutting. Journal of Applied Physics 1945,16, pp. 318-24. 
[10] METELSKI, A., KRILE, S., MARUDA, R. W. et al. (2015). Taguchi design of experiment versus dynamic programming approach in the optimization of turning process In: Applied Mechanics and Materials, ISSN 1662-7482, Vol. 808, pp 66-71

[11] MOLINARI, A., MOUFKI, A. (2008). The Merchant's model of orthogonal cutting revisited: A new insight into the modelling of chip formation, International Journal of Mechanical Sciences, 50, pp.124-131.

[12] MONKA, P. (2001). Turning tool geometric characteristics identification from machined surface roughness point of view - Doctoral Thesis (In Slovak language), Technical University of Kosice, 158 pp. and 173 pp. of supplements

[13] MOUFKI, A., MOLINARI, A., DUDZINSKI, D. (1998). Modelling of orthogonal cutting with a temperature depend-ent friction law. Journal of the Mechanics and Physics of Solids, 46(10), pp. 2103-2138.

[14] ÖTZEL, T. (2009) Computation modelling of 3D turning: Influence of edge micro-geometry of forces, stresses, fric-tion and tool wear in PcBN tooling. In: Journal of Materials Processing Technology 209, pp. 5167-5177.

[15] PILC, J., VASILKO, K. (2013). Development and applications of a rotating turning tool In: Manufacturing Technology, Volume 13, Issue 2, pp. 226-231

[16] RECH, J. et.al (2005). Influence of cutting edge radius on the wear resistance of PM-HSS milling inserts. In: Wear 259, pp. 1168-1176.

[17] SADILEK, M. et al (2011). Aspects of using tool axis inclination angle, Technical Gazette, 57, pp. 681-688.

[18] SERTIC, J., KOZAK, D., SAMARDZIC, I. (2014). Calculation of Reaction Forces in the Boiler Supports Using the Method of Equivalent Stiffness of Membrane Wall, In: Scientific World Journal, Vol. 2014, 12 p.

[19] STOJADINOVIC, S.M., MAJSTOROVIC, V.D. (2014). Developing engineering ontology for domain coordinate metrology, In. FME Transactions, vol. 42(3), pp. 249-255

[20] VASILKO, K., PILC, J. (2013). New technological knowledge of the rotary turning tool, In: Manufacturing Technology, Volume 13, Issue 4, pp. 571-575

[21] VENTURA, C.E.H., KÖHLER,J., DENKANA, B. (2013). Cutting edge preparation of PCBN inserts by means of grinding and its application in hard turning. In: CIRP Journal of Manufacturing Science and Technology 6, 2013, 246-253

[22] WYEN, C.F., WEGENER, K. (2010). Influence of cutting edge radius on cutting forces in machining titani-um. In: CIRP Annals - Manufacturing Technology 59, 2010, 93-96

[23] ZETEK, M., CESAKOVA, I., SVARC, V. (2014). Increasing Cutting Tool Life when Machining Inconel 718, In: Procedia Engineering 69, 2014, 115-1124 